\title{
PENGARUH PERSEPSI GURU TENTANG TIK TERHADAP PEMANFAATAN TEKNOLOGI INFORMASI DAN KOMUNIKASI DALAM PEMBELAJARAN IPA SMA/MA Se-KECAMATAN GERUNG
}

\author{
Nur Hudayati $^{1 *}$, Yayuk Andayani ${ }^{1}$, Eka Junaidi ${ }^{1}$ \\ ${ }^{12}$ Program Studi Pendidikan Kimia, Universitas Mataram. Jalan Majapahit No. 62 \\ Mataram, NTB 83112, Indonesia. \\ * Coressponding Author. E-mail: hudayatiyusuf27@gmail.com
}

Received: 26 Novermber 2020

Accepted: 30 Mei 2021

Published: 30 Mei 2021

doi: $10.29303 /$ cep.v4i1.2233

\begin{abstract}
Penelitian ini bertujuan untuk mengetahui pengaruh persepsi guru tentang TIK terhadap pemanfaatan TIK dalam pembelajaran IPA SMA/MA se-Kecamatan Gerung. Penelitian ini dilakukan di Sekolah Menegah Atas Negeri 1 Gerung, Sekolah Menegah Atas Negeri 2 Gerung dan Madrasah Aliyah Negeri Gerung. Penelitian ini merupakan penelitian kuantitatif expost facto. Teknik pengambilan sampel dengan sampling jenuh diperoleh 22 sampel. Pengambilan data persepsi guru tentang TIK dan pemanfaatan TIK dalam pembelajaran IPA menggunakan angket tertutup skala likert. Teknik analisis data dilakukan dengan analisis regresi dan korelasi. Berdasarkan hasil pengolahan data diperoleh bahwa antara persepsi guru tentang TIK terhadap pemanfaatan TIK dalam pembelajaran IPA memiliki pengaruh positif. Pengaruh tersebut dapat dibuktikan berdasarkan nilai $r_{x y}$ sebesar 0,45 yang menunjukkan hubungan tersebut berkategori sedang.
\end{abstract}

Kata Kunci: Persepsi, TIK.

\section{The Effect of Teachers' Perception of ICT on The Utilization of Information and Communication Technology in Science Learning SMA / MA in Gerung West Lombok}

\begin{abstract}
This study aims to determine the effect of teacher perceptions of ICT on the use of ICT in science learning for SMA / MA in Gerung West Lombok. This research was conducted in Senior High School 1 Gerung, Senior High School 2 Gerung and Islamic Senior High School West Lombok. This research is an ex post facto quantitative research. The sampling technique with saturated sampling obtained 22 samples. Collecting data on teacher perceptions of ICT and the use of ICT in science learning used a Likert scale closed questionnaire. The data analysis technique was done by using regression analysis and correlation. Based on the results of data processing, it showed that teachers' perceptions of ICT towards the use of ICT in science learning had a positive effect. This result based on $r_{x y}$ value of 0.45 which indicated the relationship is in the medium category.
\end{abstract}

Keywords: Perception, utilization, ICT. 


\section{Chemistry Education Practice, 4 (1), 2021 - 85}

Hudayati, Andayani, Junaidi

\section{PENDAHULUAN}

Pendidikan merupakan tolak ukur dalam menentukan kemajuan suatu bangsa.Pendidikan pada abad ke-21 harus mendorong generasi muda untuk dapat mengembangkan potensi dirinya dengan terus berinovasi dan berkarya sehingga bisa tetap survive dalam menghadapi perubahan di era globalisasi. Perubahan ini dapat diantisipasi dengan menguasai keterampilan abad ke-21. Keterampilan abad ke-21 merupakan keterampilan yang dibutuhkan oleh peserta didik supaya berhasil dalam menghadapi tantangan kehidupan yang semakin kompleks dan penuh dengan ketidakpastian serta berhasil dalam karir di dunia kerja (Redhana, 2019).

Salah satu keterampilan abad ke-21 yang harus dikuasai oleh peserta didik yaitu keterampilan literasi teknologi informasi dan komunikasi. Teknologi informasi dan komunikasi (TIK) atau information and communication technology (ICT) adalah alat yang mendapat nilai tambah dalam menghasilkan suatu informasi yang cepat, lengkap, akurat, transfaran dan mutakhir. Oleh karena itu, TIK dapat diartikan sebagai segala sesuatu yang memudahkan manusia dalam menyalurkan informasi secara cepat dan efektif, baik berupa program maupun peralatan (Munir, 2009).

Keterampilan abad ke-21 ini tidak dimiliki sejak lahir akan tetapi diperoleh dari proses latihan, belajar dan pengalaman sehingga efektif jika ditempuh melalui jalur pendidikan. Solusi yang diberikan oleh pemerintah Indonesia adalah dengan menerapkan kurikulum 2013. Kurikulum 2013 merespon dan mengakomodasi perkembangan dalam meningkatkan kualitas pembelajaran. Pengakomodasian tersebut dilakukan dengan mengintegrasikan TIK pada semua mata pelajaran termasuk semua mata pelajaran sains seperti biologi, fisika, kimia dan matematika. Sains atau Ilmu Pengetahuan Alam yang sering di singkat IPA merupakan mata pelajaran yang lebih menekankan pada pengalaman secara langsung untuk mampu memahami alam sekitar secara ilmiah (Wiyanto \& Yulianti, 2009).

Guru sebagai ujung tombak pendidikan dituntut untuk memiliki kemampuan di bidang TIK. Tuntutan tersebut tertera dalam Permendiknas Nomor 16 Tahun 2007 tentang standar kualifikasi akademik dan kompetensi guru. Pada sub bab kompetensi pedagogik poin lima, guru dituntut untuk mampu memanfaatkan
TIK untuk kepentingan penyelenggaraan kegiatan pengembangan yang mendidik.

Kemendikbud (2014) menjelaskan bahwa, fungsi integrasi TIK dalam pembelajaran adalah untuk mengembangkan sumber belajar dan media pembelajaran, persiapan pembelajaran, proses pembelajaran, penilaian pembelajaran dan pelaporan hasil belajar. Hal ini dilakukan untuk meningkatkan mutu dan kualitas pembelajaran.

Kenyataan yang terjadi saat ini di sekolah masih banyak guru IPA yang memiliki kendala dalam memanfaatkan TIK dalam pembelajaran yang disebabkan oleh beberapa faktor. Salah satunya yaitu persepsi guru terhadap TIK. Persepsi adalah pengalaman tentang suatu objek, peristiwa atau hubungan-hubungan yang diperoleh seseorang dengan cara menyimpulkan informasi dan menafsirkan pesan (Rakhmat, 2015).

Persepsi guru menjadi salah satu faktor yang menentukan keterlaksanaan pemanfaatan TIK untuk kegiatan pembelajaran IPA. Faktor ini memberikan sumbangsih sebagai pendorong seorang guru IPA untuk menciptakan pembelajaran di kelas maupun maya dengan memanfaatkan TIK dalam pembelajaran secara efektif. Sehingga dapat menbentuk sumber daya manusia (SDM) yang unggul sehingga memiliki daya saing tinggi di era globalisasi (Siahaan, 2014).

Oleh kerena itu, perlu dilakukannya penelitian pengaruh persepsi guru tentang TIK terhadap pemanfaatan Teknologi Informasi dan Komunikasi dalam pembelajaran IPA SMA/MA Se-Kecamatan Gerung.

\section{METODE}

Penelitian ini dilaksanakan pada bulan November-Desember 2019 di tiga sekolah, yaitu SMAN 1 Gerung, SMAN 2 Gerung dan MAN Lombok Barat. Jenis penelitian ini kuantitatif $e x$ post facto merupakan penelitian yang dilakukan untuk meneliti suatu variabel bebas yang telah terjadi ketika penelitian mulai dengan pengamatan variabel yang terikat dalam suatu suatu penelitian (Sugiyono, 2017).

Variabel dalam penelitian ini adalah persepsi guru IPA tentang TIK sebagai variabel bebas (X) dan pemanfaatan TIK dalam pembelajaran IPA oleh guru IPA se- Kecamatan Gerung sebagai variabel terikat (Y).

Populasi dalam penelitian ini meliputi seluruh guru mata pelajaran IPA yang terdiri dari guru kimia, fisika dan biologi di SMA/MA seKecamatan Gerung yang berjumlah 22 Guru. 


\section{Chemistry Education Practice, 4 (1), 2021 - 86}

Hudayati, Andayani, Junaidi

Teknik yang digunakan dalam pengambilan sampel yaitu dengan menggunakan teknik sampling jenuh. Sampel pada penelitian ini meliputi seluruh semua popolasi.

Instrumen pada penelitian ini berupa angket (kuesioner) tertutup (berskala Likert) yang dimodifikasi dari Eko Nugroho (2013). Penelitian ini memiliki dua variabel sehingga instrumen yang digunakan ada dua yakni angket persepsi guru tentang teknologi informasi dan komunikasi (TIK) dan angket pemanfaatan TIK dalam pembelajaran IPA. Instrumen kuesioner yang telah disusun dapat digunakan setelah di uji validitasnya menggunakan 2 uji validitas yaitu empiris dan kontruksi. Validitas empiris menggunakan rumus Korelasi Pearson Product Moment dengan perhitungan secara manual dan Microsoft excel 2007. Validitas konstruk dilakukan oleh validator. Validator pada penelitian ini adalah dosen pendidikan kimia. Selanjutnya untuk mengukur tingkat kepercayaan atau seberapa dapat diandalkannya angket yang telah divalidasi menjadi alat ukur dalam penelitian ini dilakukan uji reliabilitas instrumen menggunkan rumus Alpha Cronbach.

Teknik pengumpulan data pada penelitian ini menggunakan instrumen angket yang didistribusikan ke sampel yang telah ditentukan di tiga sekolah yaitu SMAN 1 Gerung, SMAN 2 Gerung, dan MAN Lombok Barat. Angket dibagikan kepada guru secara acak yang sesuai dengan jumlah sampel yang telah ditetapkan. Kemudian angket dikumpulkan kembali dengan jumlah yang sama dengan angket yang telah dibagikan.

Teknik analisis data menggunakan statistik inferensial karena untuk menguji kebenaran hipotesis yang di ajukan. Jenis hipotesis yang diuji merupakan hipotesis assosiatif, yaitu dugaan tentang adanya hubungan antar variabel dalam populasi yang diuji melalui hubungan antar variabel dalam sampel yang diambil dari populasi tersebut. Bentuk hubungan antar variabel yang dimaksudkan dalam penelitian ini yaitu hubungan sebab akibat (kausal).

Berdasarkan hal-hal tersebut statistik parametris yang sesuai untuk digunakan dalam penelitian ini yaitu korelasi product moment pearson untuk mengukur besarnya hubungan dua variabel yaitu variabel persepsi guru tentang TIK (X) dan variabel pemanfaatan TIK dalam pembelajaran IPA (Y). Statistik parametris memerlukan beberapa asumsi yang harus terpenuhi, sehingga sebelum melakukan statistik parametris, terlebih dahulu dilakukan uji asumsi yaitu uji normalitas data dan untuk analisis regresi harus terpenuhi asumsi linearitas (Sugiyono, 2017). Dalam penelitian ini, data yang akan di uji normalitasnya adalah hasil dari angket persepsi guru tentang TIK dan angket pemanfaatan TIK dalam pembelajaran IPA. Pengujian normalitas data pada penelitian ini menggunakan Chi Kuadrat $\left(\chi^{2}\right)$.

Menurut Hadi (2004) Uji linearitas dilakukan untuk mengetahui hubungan anatara variabel bebas $(\mathrm{X})$ dan variabel terikat $(\mathrm{Y})$ berbentuk linear. Uji linearitas dilakukan dengan menggunakan uji F. Hasil yang diperoleh melalui uji linieritas akan menentukan teknik analisis regresi yang digunakan, apabila dari hasil uji linieritas didapatkan kesimpulan bahwa distribusi data penelitian dikategorikan linier maka penelitian harus diselesaikan dengan teknik analisis regresi linier. Demikian sebaliknya apabila ternyata tidak linier maka distribusi data penelitian harus dianalisis dengan teknik analisis regresi non-linier.

\section{HASIL DAN PEMBAHASAN}

Persepsi guru yang dimaksud di tinjau dari sudut pandang guru bidang pelajaran Ilmu Pengetahuan Alam (IPA) tentang kebermanfaatan Teknologi Informasi dan Komunikasi (TIK) baik kebermanfaatannya dari sisi e-administrasi, dan sisi e-pembelajaran. Persepsi guru pada pemanfaatan TIK dalam sangat penting di lingkungan sekolah karena menjadi landasan bagi pembelajaran yang efektif dan produktif. Persepsi guru pada pemanfaatan TIK yang baik di harapkan terciptanya kinerja guru yang lebih baik yang akan mendukung peningkatan kualitas pendidikan.

Data yang diperoleh dari hasil penelitian dalam bentuk interval diolah untuk menguji hipotesis dengan menggunakan statistik. Dalam banyak prosedur penelitian statistik regresi sederhana korelasi Pearson product moment yang digunakan pada penelitian ini terlebih dahulu peneliti melakukan uji asumsi yaitu uji normalitas dan uji linearitas untuk memastikan data berdistribusi normal dan berpola linear. Berdasarkan hasil uji asumsi data yang diperoleh dari perhitungan menunjukkan data terdistribusi normal dan berpola linear antara variabel $\mathrm{X}$ dengan variabel $\mathrm{Y}$. 


\section{Analisis Regresi Sederhana antara Persepsi Guru tentang TIK dengan Pemanfaatan TIK dalam Pembelajaran IPA}

Analisis regresi yang digunakan dalam penelitian ini merupakan analisis regresi sederhana yaitu analisis yang hanya memiliki satu variabel bebas atau variabel atribut (X) dan satu variabel terikat $(\mathrm{Y})$. Pada penelitian ini variabel $\mathrm{X}$ adalah persepsi guru tentang TIK sementara variabel $\mathrm{Y}$ adalah pemanfaatan TIK dalam pembelajaran IPA. Tujuan analisis regresi sederhana untuk memprediksi seberapa jauh perubahan nilai pemanfaatan TIK dalam pembelajaran IPA apabila persepsi guru tentang TIK diketahui atau diubah-ubah nilainya. Berdasarkan perhitungan yang telah dilakukan pada uji regresi sederhana yang diperoleh persamaan regresi berikut:

$$
\mathrm{Y}=0,728 \mathrm{X}+15,0268
$$

Berdasarkan persamaan regresi diatas dapat diketahui bahwa, apabila nilai persepsi guru tentang TIK (X) dinaikkan 1 poin maka nilai pemanfaatan TIK dalam pembelajaran IPA (Y) bertambah 0,728 poin. Apabila nilai persepsi guru tentang TIK (X) sama dengan nol maka nilai pemanfaatan TIK dalam pembelajaran IPA (Y) adalah 15,02 poin. Karena nilai koefisien regresi bernilai positif (+), maka dapat dikatakan bahwa persepsi guru tentang TIK (X) berpengaruh positif terhadap pemanfaatan TIK dalam pembelajaran IPA (Y). Angka positif ataupun negatif yang di hasilkan pada intercept a tidak harus diinterpretasikan. Hal ini sesuai dengan pendapat Dougherly (2016) dalam bukunya yang berjudul Introduction to Econometrics $2^{\text {nd }}$ Edition menyatakan bahwa "the constant sometimes have a clear meaning, but sometimes not". Hal ini dipertegaas oleh William Mendan Hall dalam bukunya yang berjudul A second course in statistic: Regression Analysis $\left(7^{\text {th }}\right.$ edition) menyatakan bahwa konstanta a tidak selalu memiliki interpretasi praktikal, sehingga nilai intercept a bisa di terjemahkan dan bisa juga tidak diterjemahkan.

Lebih jelasnya dapat dilihat pada grafik di Gambar 1 berikut:

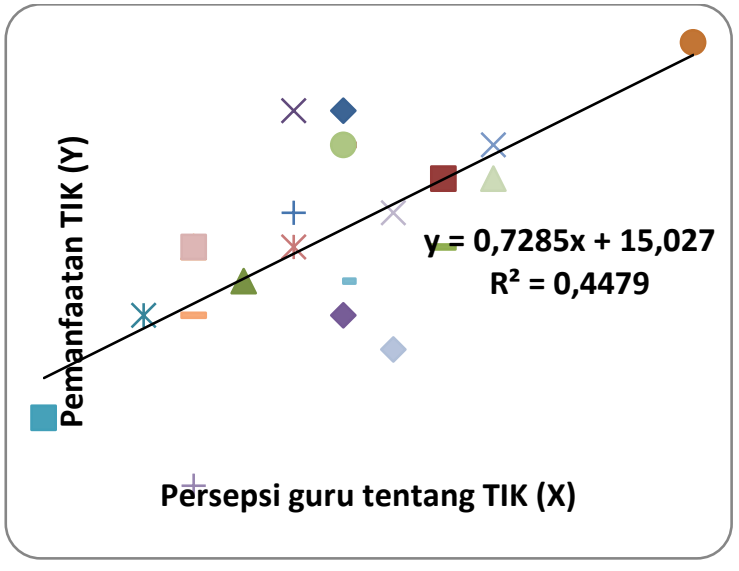

Gambar 1. Grafik Persamaan Regresi Sederhana

Persamaan regresi yang diperoleh digunakan untuk menguji signifikansi regresi dengan menggunakan uji F. Tujuan dilakukannya uji ini untuk melihat makna pengaruh yang diberikan variabel $X$ (persepsi guru tentang TIK) terhadap variabel $\mathrm{Y}$ (pemanfaatan TIK dalam pembelajaran IPA). Hasil perhitungan statistik analisis regresi sederhana diperoleh $F_{\text {hitung }}$ sebesar 0,74 dengan nilai $\mathrm{F}_{\text {tabel }}=4,35$ berdasarkan tabel uji signifikasi pada taraf signifikan $5 \%$ dengan $(\mathrm{dk}$ pembilang $=1$ dan $\mathrm{dk}$ penyebut $=\mathrm{n}-2=22-2$ $=20$ ). Karena nilai $F_{\text {hitung }}<F_{\text {tabel }}$ maka nilai regresi sederhana berdasarkan data penelitian adalah tidak signifikan, sehingga Ha ditolak, artinya bahwa koefisien arah regresi (b) sama dengan nol. Hal ini terjadi karena ukuran sampel yang digunakan kecil yakni 22 orang sehingga akan sulit untuk menemukan hubungan yang signifikan. Sejalan dengan teori menurut Widhiarso (2011) semakin kecil ukuran sampel maka semakin besar nilai kritis yang digunakan sebagai acuan. Begitupun sebaliknya semakin besar ukuran sampel yang dipakai semakin kecil nilai kritis yang dipakai sebagai acuan.

\section{Korelasi Sederhana antara Persepsi Guru Tentang TIK dengan Pemanfaatan TIK dalam Pembelajaran IPA}

Analisis korelasi sederhana menggunakan analisis Pearson Product Moment. Berdasarkan hasil pengolahan data diperoleh bahwa antara persepsi guru tentang TIK terhadap pemanfaatan TIK dalam pembelajaran IPA memiliki pengaruh positif. Pengaruh tersebut dapat dibuktikan berdasarkan nilai $r_{x y}$ sebesar 0,45 . Nilai tersebut dikonsultasikan pada tabel pedoman interpretasi koefisien korelasi yang menunjukkan hubungan tersebut berkategori sedang karena terletak di antara 0,40 - 0,599. 


\section{Chemistry Education Practice, 4 (1), 2021 - 88}

Hudayati, Andayani, Junaidi

Kenyataan ini menyatakan fakta yang harus diperhatikan dan ditindak lanjuti oleh kepala sekolah di SMA/MA Negeri di Kecamatan Gerung untuk memperhatikan dan mengembangkan pemanfaatan TIK dalam pembelajaran bidang IPA yang nantinya terlaksana secara efektif untuk mencapai peningkatan kualitas pendidikan.

Koefisien korelasi 0,45 yang di peroleh menunjukkan bahwa arah hubungan antara variabel persepsi guru tentang TIK dan variabel pemanfaatan TIK dalam pembelajaran IPA adalah positif yang artinya semakin tinggi persepsi guru tentang TIK maka semakin tinggi pula pemanfaatan TIK dalam pembelajaran IPA. Sebaliknya semakin rendah persepsi guru tentang TIK maka semakin rendah pula pemanfaatan TIK dalam pembelajaran IPA. Bila seorang guru memandang positif tentang TIK maka seorang guru akan berupaya untuk dapat menerima dan memadukan TIK dalam melaksanakan tugasnya dalam proses pembelajaran, baik tugas dalam eadministrasi maupun tugas dalam epembelajaran.

Nilai dari koefisien korelasi sebesar 0,45 tersebut diakumulasikan sehingga didapatkan nilai koefisien determinasi sebesar $20 \%$ yang berarti persepsi guru tentang TIK memberikan pengaruh sebesar $20 \%$ terhadap pemanfaatan TIK dalam pembelajaran IPA dan sebesar $80 \%$ dipengaruhi oleh variabel lain yang tidak diteliti dalam penelitian ini. Ini berarti bahwa pemanfaatan TIK dalam pembelajaran IPA juga dipengaruhi oleh faktor yang lain.

Berikut ini beberapa penlitian tentang faktor lain yang mempengaruhi pemanfaatan TIK dalam pembelajaran. Berdasarkan penelitian Marzal dan Damris (2015) fakor pengetahuan menjadi salah satu pengaruh terhadap implementasi TIK. Berdasarkan hasil penelitian yang dilakukan dapat diketahui sebanyak $74 \%$ responden memiliki tingkat pengetahuan TIK yang rendah berbading lurus dengan $88 \%$ responden memiliki tingkat implementasi TIK berada pada tingkat rendah. Tingkat implementasi TIK guru matematika SMA/MA di Kabupaten Tanjung tak satupun dari responden memiliki tingkat implementasi TIK tinggi. Faktor lainnya di teliti oleh Destiana (2014) menyatakan bahwa terdapat pengaruh faktor sosial terhadap pemanfaatan TIK dengan nilai koefisien faktor sosial pada Output Path Coefficient sebesar 0,315 yang berarti terdapat pengaruh positif sebesar $31,5 \%$ terhadap pemanfaatan TIK. Secara logis hal ini dapat di pesepsikan bahwa kondisi di lingkungan sekitar yang mendukung dapat menyebabkan guru termotivasi untuk turut serta menggunakan sistem atau teknologi yang digunakan dilingkunganmya. Faktor sosial yang mempengaruhi dalam pemanfaatan TIK oleh guru salah satunya dukungan atasan. Dukungan atasan untuk menggunakan perangkat TIK dalam bekerja akan sangat mempengaruhi pemanfaatan TIK oleh guru. Dukungan yang di maksudkan dapat berupa penyediaan fasilitas, pelatihanpelatihan dan teknisi yang dapat membantu guru saat mengalami kesulitan.

\section{SIMPULAN}

Berdasarkan hasil penelitian terdapat pengaruh yang positif dan signifikan antaraPersepsi Guru Tentang TIK Terhadap Pemanfaatan Teknologi Informasi dan Komunikasi dalam Pembelajaran IPA SMA/MA Se-Kecamatan Gerung dilihat dari nilaikoefisien korelasi product momen $\left(\mathrm{r}_{\mathrm{xy}}\right)$ yang diperoleh sebesar 0,45 dengan tingkat korelasi sedang. Variabel persepsi guru tentang TIK memberikan kontribusi terhadap pemanfaatan TIK dalam pembelajaran IPA sebesar 20\% dan sisanya $80 \%$ dipengaruhi oleh variabel lain yang tidak diteliti dalam penelitian ini.

\section{DAFTAR PUSTAKA}

Destiana, B., \& Soenarto, S. (2014). Faktor determinan pemanfaatan TIK dan pengaruhnya terhadap kinerja guru SMK di Kabupaten Gunungkidul. Jurnal Pendidikan Vokasi, 4(3).

Dougherty, C. (2016). Introduction to econometrics. Oxford University Press, USA.

Hadi, S. (2004). Metodologi Research, Jilid 2.

Kemendiknas. (2007). Peraturan Menteri Pendidikan Nasional Republik Indonesia Nomor 16 Tahun 2007 Tentang Standar Kualifikasi Akademik dan Kompetensi Guru. Jakarta: Kemendiknas.

Kemendiknas. 2014. Pedoman Pelaksanaan Tugas Guru TIK dan KKPI. Jakarta: Kemendikbud.

Mizal J., Damris D. (2015). Investigasi Pengetahuan, Keterampilan dan Implementasi TeknologiInformasi dan Komunikasi Matematika SMA/MA Kabupaten Tanjung. Edu-Sains, 2(4): 3745.

Munir. (2009). Pembelajaran jarak jauh berbasis Teknologi Informasi dan Komunikasi. Bandung: Alfabeta. 
Chemistry Education Practice, 4 (1), 2021 - 89

Hudayati, Andayani, Junaidi

Nugroho, E. (2013). Pengaruh Persepsi Guru Tentang Tik Dan Motivasi Kerja Guru Terhadap Pemanfaataan Teknologi Informasi Dan Komunikasi Dalam Pembelajaran SMK RSBI Bidang Keahlian Teknik Elektro Di DIY. Universitas Negeri Yogyakarta.

Rakhmat, J. (2015). Psikologi komunikasi.

Redhana, I. W. (2019). Mengembangkan keterampilan abad ke-21 dalam pembelajaran kimia. Jurnal Inovasi Pendidikan Kimia, 13(1).

Siahaan, S. (2015). Pemanfaatan Teknologi Informasi dan Komunikasi dalam Pembelajaran: Peluang, Tantangan, Dan Harapan. Jurnal Teknodik, 19(3), 321-332.

Sugiyono. (2016). Statistika untuk Penelitian. Bandung: Alfabeta.

Sugiyono. (2017). Statistika untuk Penelitian. Bandung: Alfabeta.

Widhiarso, W. (2011). Berurusan Dengan Outlier. Yogyakarta: Universitas Gajah Mada.

Wiyanto \& Yulianti. (2009). Perancangan Pembelajaran Inovatif. Semarang: Lembaga Pengembangan Pendidikan dan Profesi Universitas Negeri Semarang. 